\title{
New Penta Bismuth Based Alloy for Shielding Blocks in Mega-Volt Radiotherapy
}

\author{
Abu Bakr El- Bediwi \\ Metal Physics Lab., Physics \\ Department, Faculty of Science, \\ Mansoura University \\ Mansoura, Egypt
}

\author{
Feryal Dawood \\ Basic education college \\ University of Diayala \\ Iraq
}

\author{
Mustafa Kamal \\ Metal Physics Lab., Physics \\ Department, Faculty of Science, \\ Mansoura University \\ Mansoura, Egypt
}

\begin{abstract}
Microstructure, thermal, electrical and mechanical properties of penta $\mathrm{Bi}-\mathrm{Sn}-\mathrm{Pb}$ based alloys have been investigated. Matrix structure (Formed crystalline phases) and measured physical properties of $\mathrm{Bi}-\mathrm{Sn}$ - $\mathrm{Pb}$ - In- $\mathrm{X}(\mathrm{X}=\mathrm{Cd} / \mathrm{or} \mathrm{Zn}$ ) penta alloys changed with varying composition. The new penta fusible, $\mathrm{Bi}_{50} \mathrm{~Pb}_{15} \mathrm{Sn}_{22} \mathrm{Cd}_{3} \mathrm{In}_{10}$, alloy has best properties such as high density, low melting point and friendly environmental, (reduced toxicity elements $\mathrm{Pb}$ and $\mathrm{Cd}$ by $40 \%$ and $75 \%$, compared used alloys), for shielding blocks in mega-volt radiotherapy. The melting temperature of $\mathrm{Bi}_{50} \mathrm{~Pb}_{15} \mathrm{Sn}_{22} \mathrm{Cd}_{3} \mathrm{In}_{10}$ alloy is $\sim 58{ }^{\circ} \mathrm{C}$ and it is density is $10.117 \mathrm{gm} / \mathrm{cm}^{3}$. The elastic modulus of $\mathrm{Bi}_{50} \mathrm{~Pb}_{15} \mathrm{Sn}_{22} \mathrm{Cd}_{3} \mathrm{In}_{10}$ is $29.03 \mathrm{Gpa} \mathrm{Vickers}$ hardness and internal friction values of $\mathrm{Bi}_{50} \mathrm{~Pb}_{15} \mathrm{Sn}_{22} \mathrm{Cd}_{3} \mathrm{In}_{10}$ alloy are $9.72 \mathrm{Kg} / \mathrm{mm}^{2}$ and 0.085 . The $\mathrm{Bi}_{50} \mathrm{~Pb}_{15} \mathrm{Sn}_{22} \mathrm{Cd}_{3} \mathrm{In}_{10}$ alloy consists of rhombohedral $\mathrm{Bi}$ phase, tetragonal $\mathrm{Sn}$ phase, face centered cubic $\mathrm{Pb}$ phase, hexagonal $\mathrm{Cd}$ phase, face centered cubic $\mathrm{In}$ phase, $\mathrm{Pb}{ }_{7} \mathrm{Bi} \mathrm{a}_{3}$ and $\mathrm{SnBi}$ intermetallic compounds.
\end{abstract}

Key words: shielding blocks, fusible alloys, thermal and mechanical properties, electrical resistivity

\section{INTRODUCTION}

Over the past few years fusible alloys have become a hot subject because they important for industrial and medical applications. Now is the time to understand the correlation between microstructure and physical properties of fusible alloys for solder, bearing and shielding blocks applications. There are an enormous number of alloys made by metals as bismuth, lead; tin and cadmium have in common the feature of a low melting point. In the past they were commonly known as Lipowitz's, Wood's, D'Arcet and Rose alloys and now they are known as Arconim's alloys. In our days other alloys having slightly different compositions in order to fatherly improve their peculiarities had replaced them. Structure, growth properties and physical metallurgy of a series of $\mathrm{Pb}-\mathrm{Sn}-\mathrm{Cd}$ alloys containing up to $60-\mathrm{wt} . \% \mathrm{Bi}$ and $\mathrm{Pb}-$ $\mathrm{Sn}-\mathrm{Bi}$ were investigated [1]. The results showed that, formation of metastable crystalline phase in the range of composition investigated causes a pronounced increased the electrical resistivity. Adding bismuth to PbCdSn had to the appearance of the crystalline metastable phase which produced hardening effect [2]. Also bismuth atoms act as scattering centers and increasing their concentrations caused an enhancement of resistivity. The physical characteristic of lipowitz's metal and bismuth-lead eutectic alloys as a shielding block for mega voltage therapy machine were studied and analyzed. Internal friction of irradiated and non-irradiated alloys is sensitive to the chemical composition used alloys [3]. Structure, mechanical and electrical transport properties of $\mathrm{Pb}_{60} \mathrm{Sn}_{38} \mathrm{X}_{2}(\mathrm{X}=\mathrm{Sb}, \mathrm{Bi}$, or $\mathrm{Ag}$ in weight percent as ternary additions) were investigated. Ledbetter's theoretical values of the ratio of shear modulus to elastic modulus, $\mu / \mathrm{E}$, are in a good agreement with the experimental results [4]. The crystalline metastable $\chi(\mathrm{Pb}-\mathrm{Bi})$ phase was appeared in $\mathrm{Pb}_{50} \mathrm{Sn}_{50-\mathrm{x}} \mathrm{Bi}_{\mathrm{x}}(\mathrm{x}=30$ and 50 wt. \%) alloys and the lowest value of Vickers hardness was attributed to the formation of intermediate metastable phases [5]. Mechanical and electrical properties of $\mathrm{PbBiSnCd}$ were dependence on tin content obtained [6]. The ductility of the binary Bi-Sn eutectic alloy has significantly improved by adding small amount Ag [7]. Metastable shift of the solubility limit in Sn-Bi alloys containing 15, 20 and 25 at. \% bismuth was produced by splat quenching [8]. The effect of splat cooling on crystal structures and heats of formation of non-equilibrium intermediate phases of $\mathrm{Pb}-\mathrm{Bi}$ alloy was studied [9]. Solid solubility extension of $\mathrm{Pb}$ in $\mathrm{Bi}$ and formation and lattice parameter of several new metastable crystalline solid phases in $\mathrm{Pb}-\mathrm{Bi}$ including complex $\mathrm{Pb}-\mathrm{Bi}$ phases was reported [10]. The crystallographic relation-ship between the phases in the Cd-Zn eutectic alloys using standard $\mathrm{x}$-ray techniques on selected areas of bulk eutectic specimens was examined [11]. Also the orientation characteristics of eutectic alloys of Bi-Cd, Cd-Sn, Sn-Zn and Al-Si were studied [12]. Microstructure, electrical, mechanical and thermal properties of rapidly solidified $\mathrm{Bi}_{58} \mathrm{Sn}_{42}$ eutectic alloy have been investigated [13]. Thermal properties and microstructure of $58 \% \mathrm{Bi}$ $42 \%$ Sn, 53\% Bi-26\% Sn-21\% Cd,70\% In-30\% Sn, 50\% Sn-50\% In and $3 \% \mathrm{Sn}-37 \% \mathrm{Bi}-10 \%$ In solder alloys have been studied and analyzed [14]. Attenuation coefficients, structure and physical properties of $\mathrm{Bi}-\mathrm{Pb}-\mathrm{Sn}$ fusible alloys were studied [15]. Microstructure, electrical, mechanical and thermal properties of melt spun bismuth- tin and bismuth- lead- tin- eutectic alloys also investigated [16, 17]. Optical microscopy, X-ray diffractometry, double bridge method, Vickers microhardness testing and dynamic resonance techniques have been used to investigate structure, electrical resistivity, hardness, internal friction and elastic modulus of quenched $\mathrm{Bi}-\mathrm{Pb}-\mathrm{Sn}-\mathrm{Cd}-\mathrm{Sb}$ penta-alloys, $\mathrm{Bi}-\mathrm{Pb}, \mathrm{Bi}-\mathrm{Pb}-\mathrm{Sn}, \mathrm{Bi}-\mathrm{Pb}-\mathrm{Cd}$ and $\mathrm{Bi}-$ $\mathrm{Pb}-\mathrm{Sn}-\mathrm{Cd}$ fusible alloys $[18,19]$. The effect of the quenching rate on structure and some physical properties of the $\mathrm{Pb}-\mathrm{Sn}-\mathrm{Cd}$ melt spun fusible alloys have been investigated by El-Bediwi [20].

The aim of our research was to produce new bismuth based alloy with superior properties as shielding blocks in mega-volt radiotherapy

\section{EXPERIMENTAL WORK}

Using elements bismuth, tin, lead, indium, cadmium and zinc have a high purity, more than $99.95 \%$. The used alloys, $\mathrm{Bi}_{50} \mathrm{~Pb}_{15} \mathrm{Sn}_{22} \mathrm{In}_{10} \mathrm{X}_{3}$ and $\mathrm{Bi}_{50} \mathrm{~Pb}_{15} \mathrm{Sn}_{28} \mathrm{In}_{4} \mathrm{X}_{3}(\mathrm{X}=\mathrm{Cd}$ or $\mathrm{Zn})$, were molten in the muffle furnace. The resulting ingots were turned and re-melted several times to increase the homogeneity of the ingots. From these ingots, long ribbons of about 3-5 mm width and $\sim 70 \mu \mathrm{m}$ thickness were prepared as the test samples by directing a stream of molten alloy 
onto the outer surface of rapidly revolving copper roller with surface velocity $31 \mathrm{~m} / \mathrm{s}$ giving a cooling rate of $3.7 \times 10^{5} \mathrm{k} / \mathrm{s}$. The samples then cut into convenient shape for the measurements using double knife cuter. Structure of used alloys was performed using an Shimadzu $\mathrm{x}$-ray diffractometer (Dx-30, Japan) of $\mathrm{Cu}-\mathrm{K} \alpha$ radiation with $\lambda=1.54056 \AA$ at $45 \mathrm{kV}$ and $35 \mathrm{~mA}$ and $\mathrm{Ni}$-filter in the angular range $2 \theta$ ranging from 20 to $100^{\circ}$ in continuous mode with a scan speed 5 $\mathrm{deg} / \mathrm{min}$. Scanning electron microscope JEOL JSM-6510LV, Japan was used to study microstructure of used samples. The melting endotherms of used alloys were obtained using a SDT Q600 V20.9 Build 20 instrument. A digital Vickers micro-hardness tester, (ModelFM-7- Japan), was used to measure Vickers hardness values of used alloys. Internal friction $\mathrm{Q}^{-1}$ and the elastic constants of used alloys were determined using the dynamic resonance method [21-23].

\section{RESULTS AND DISCUSSIONS}

\section{Microstructure}

$X$-ray diffraction patterns of $\mathrm{Bi}_{50} \mathrm{~Pb}_{15} \mathrm{Sn}_{22} \mathrm{In}_{10} \mathrm{X}_{3}$ and $\mathrm{Bi}_{50} \mathrm{~Pb}_{15} \mathrm{Sn}_{28} \mathrm{In}_{4} \mathrm{X}_{3}(\mathrm{X}=\mathrm{Cd}$ or $\mathrm{Zn})$ alloys have lines corresponding to rhombohedral $\mathrm{Bi}$ phase, tetragonal $\mathrm{Sn}$ phase, face centered cubic $\mathrm{Pb}$ phase, hexagonal $\mathrm{Cd}$ phase, face centered cubic In phase, $\mathrm{Pb}_{7} \mathrm{Bi}_{3}$ and $\mathrm{SnBi}$ intermetallic compounds as shown in Figure 1. X-ray analysis of $\mathrm{Bi}_{50} \mathrm{~Pb}_{15} \mathrm{Sn}_{22} \mathrm{In}_{10} \mathrm{X}_{3}$ and $\mathrm{Bi}_{50} \mathrm{~Pb}_{15} \mathrm{Sn}_{28} \mathrm{In}_{4} \mathrm{X}_{3}(\mathrm{X}=\mathrm{Cd}$ or $\mathrm{Zn})$ alloys show that, the change in feature of formed phases (such as intensity,

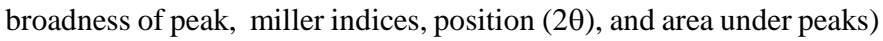
correlates to the alloy composition. Lattice parameters, (a and c), and unit volume cell $(\mathrm{V})$ of rhombohedral $\mathrm{Bi}$ phase in $\mathrm{Bi}_{50} \mathrm{~Pb}_{15} \mathrm{Sn}_{22} \mathrm{In}_{10} \mathrm{X}_{3}$ and $\mathrm{Bi}_{50} \mathrm{~Pb}_{15} \mathrm{Sn}_{28} \mathrm{In}_{4} \mathrm{X}_{3}(\mathrm{X}=\mathrm{Cd}$ or $\mathrm{Zn})$ alloys were determined and then listed in Table 1a. Adding $\mathrm{Cd} /$ or $\mathrm{Zn}$ to $\mathrm{Bi}-\mathrm{Pb}$ - $\mathrm{Sn}$ - In alloys caused a little variation in $\mathrm{Bi}$ lattice parameters and unit cell volume. Crystal particle size of rhombohedral $\mathrm{Bi}$ phase in $\mathrm{Bi}_{50} \mathrm{~Pb}_{15} \mathrm{Sn}_{22} \mathrm{In}_{10} \mathrm{X}_{3}$ and $\mathrm{Bi}_{50} \mathrm{~Pb}_{15} \mathrm{Sn}_{28} \mathrm{In}_{4} \mathrm{X}_{3}(\mathrm{X}=\mathrm{Cd}$ or $\mathrm{Zn})$ alloys are seen in Table $1 \mathrm{~b}$. Adding $\mathrm{Cd}$ to $\mathrm{Bi}-\mathrm{Pb}-\mathrm{Sn}$ - In alloys produced higher crystal size of $\mathrm{Bi}$ phase than $\mathrm{Zn}$.
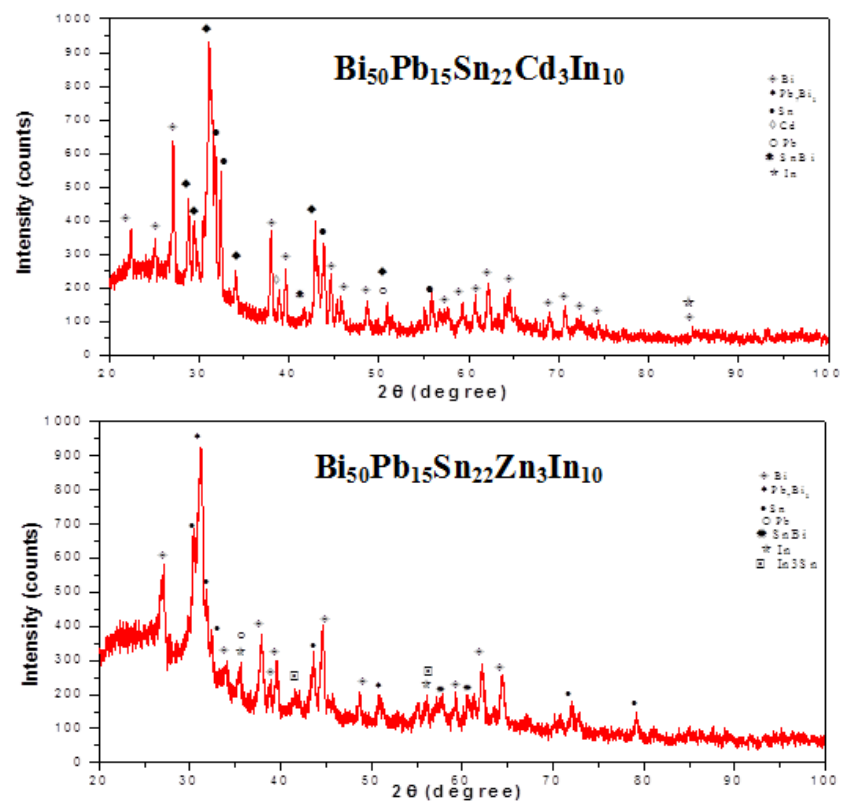
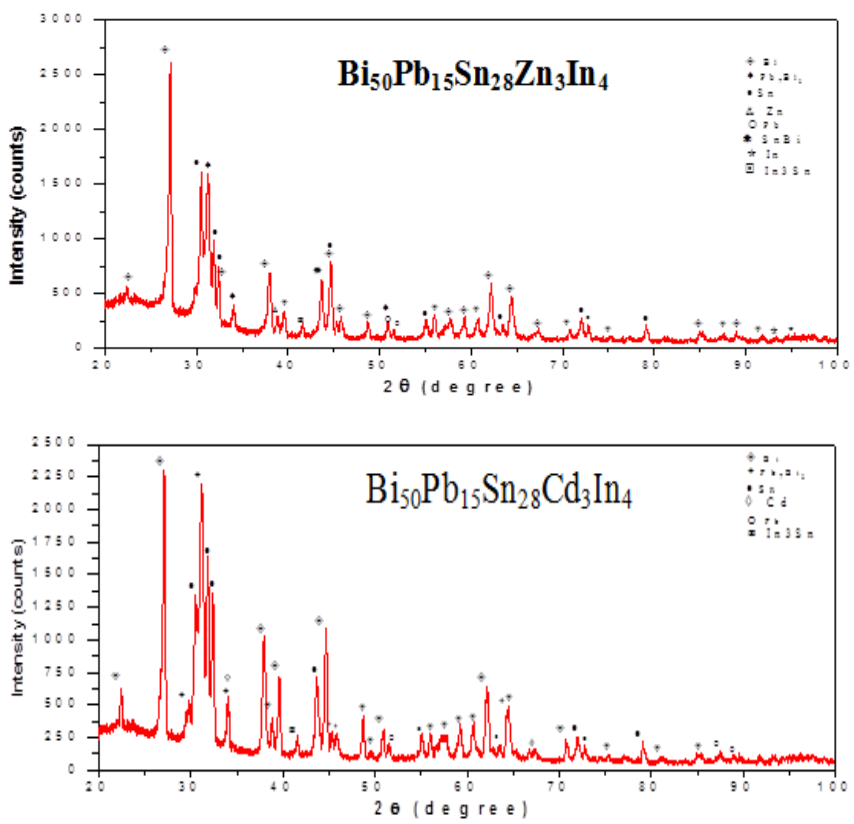

Figure 1:- $\mathrm{X}$-ray diffraction patterns of penta $\mathrm{Bi}-\mathrm{Pb}$ - $\mathrm{Sn}$ based alloys

Table 1a:-lattice parameters and unit cell volume of $\mathrm{Bi}$ in penta $\mathrm{Bi}-\mathrm{Pb}-\mathrm{Sn}$ based alloys

\begin{tabular}{|c|c|c|c|}
\hline Samples & $a_{\text {rho }} \AA$ & c $\AA$ & $\mathrm{V}^{3}$ \\
\hline $\mathrm{Bi}_{50} \mathrm{~Pb}_{15} \mathrm{Sn}_{22} \mathrm{Cd}_{3} \operatorname{In}_{10}$ & 4.748 & 11.87 & 70.766 \\
\hline $\mathrm{Bi}_{50} \mathrm{~Pb}_{15} \mathrm{Sn}_{22} \mathrm{Zn}_{3} \mathrm{In}_{10}$ & 4.816 & 12.106 & 71.962 \\
\hline $\mathrm{Bi}_{50} \mathrm{~Pb}_{15} \mathrm{Sn}_{28} \mathrm{Cd}_{3} \mathrm{In}_{4}$ & 4.754 & 11.886 & 70.994 \\
\hline $\mathrm{Bi}_{50} \mathrm{~Pb}_{15} \mathrm{Sn}_{28} \mathrm{Zn}_{3} \mathrm{In}_{4}$ & 4.753 & 11.879 & 71.014 \\
\hline
\end{tabular}

Table 1b:- crystal particle size of $\mathrm{Bi}$ rho in penta $\mathrm{Bi}-\mathrm{Pb}-\mathrm{Sn}$ based alloys

\begin{tabular}{|c|c|}
\hline Samples & Particle size $\AA$ \\
\hline $\mathrm{Bi}_{50} \mathrm{~Pb}_{15} \mathrm{Sn}_{22} \mathrm{Cd}_{3} \mathrm{In}_{10}$ & 357.64 \\
\hline $\mathrm{Bi}_{50} \mathrm{~Pb}_{15} \mathrm{Sn}_{22} \mathrm{Zn}_{3} \mathrm{In}_{10}$ & 264.646 \\
\hline $\mathrm{Bi}_{50} \mathrm{~Pb}_{15} \mathrm{Sn}_{28} \mathrm{Cd}_{3} \mathrm{In}_{4}$ & 372.43 \\
\hline $\mathrm{Bi}_{50} \mathrm{~Pb}_{15} \mathrm{Sn}_{28} \mathrm{Zn}_{3} \mathrm{In}_{4}$ & 339.46 \\
\hline
\end{tabular}

Scanning electron micrographs, SEM, of $\mathrm{Bi}_{50} \mathrm{~Pb}_{15} \mathrm{Sn}_{22} \mathrm{In}_{10} \mathrm{X}_{3}$ and $\mathrm{Bi}_{50} \mathrm{~Pb}_{15} \mathrm{Sn}_{28} \mathrm{In}_{4} \mathrm{X}_{3}(\mathrm{X}=\mathrm{Cd}$ or $\mathrm{Zn})$ alloys show heterogeneous structure as shown in Figure 2 and that agreed with $\mathrm{X}$-ray analysis. Adding $\mathrm{Cd}$ / or $\mathrm{Zn}$ to $\mathrm{Bi}-\mathrm{Pb}$ - $\mathrm{Sn}$ - In alloys caused a change in matrix microstructure of $\mathrm{Bi}-\mathrm{Pb}-\mathrm{Sn}$ alloy. 

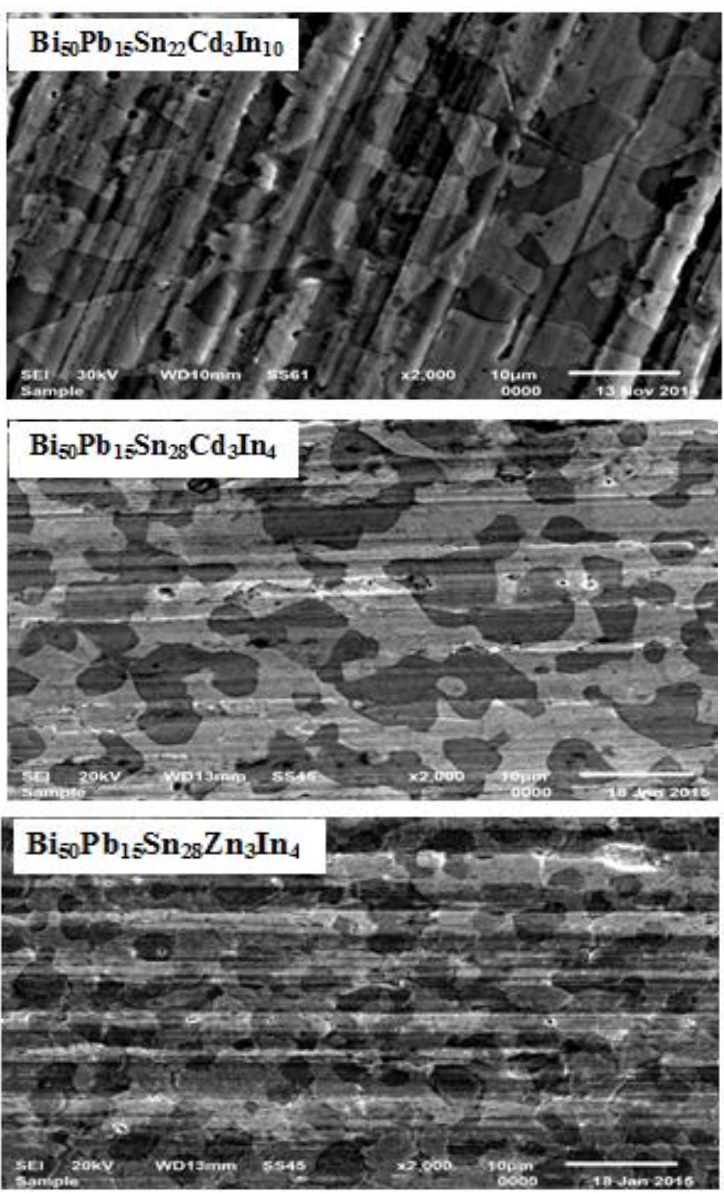

Figure 2:- SEM of penta $\mathrm{Bi}-\mathrm{Pb}-\mathrm{Sn}$ based alloys

\section{Thermal properties}

Thermal analysis is often used to study solid state transformations as well as solid-liquid reactions. Figure 3 shows DSC thermographs of $\mathrm{Bi}_{50} \mathrm{~Pb}_{15} \mathrm{Sn}_{22} \mathrm{In}_{10} \mathrm{X}_{3}$ and $\mathrm{Bi}_{50} \mathrm{~Pb}_{15} \mathrm{Sn}_{28} \mathrm{In}_{4} \mathrm{X}_{3}(\mathrm{X}=\mathrm{Cd}$ or $\mathrm{Zn})$ alloys. Little variation occurred in exothermal peaks of $\mathrm{Bi}_{50} \mathrm{~Pb}_{15} \mathrm{Sn}_{22} \mathrm{In}_{10} \mathrm{X}_{3}$ and $\mathrm{Bi}_{50} \mathrm{~Pb}_{15} \mathrm{Sn}_{28} \mathrm{In}_{4} \mathrm{X}_{3}(\mathrm{X}=\mathrm{Cd}$ or $\mathrm{Zn})$ alloys after adding $\mathrm{Cd} / \mathrm{or} \mathrm{Zn}$. The melting temperature and other thermal properties of $\mathrm{Bi}_{50} \mathrm{~Pb}_{15} \mathrm{Sn}_{22} \mathrm{In}_{10} \mathrm{X}_{3}$ and $\mathrm{Bi}_{50} \mathrm{~Pb}_{15} \mathrm{Sn}_{28} \mathrm{In}_{4} \mathrm{X}_{3}(\mathrm{X}=\mathrm{Cd}$ or $\mathrm{Zn})$ alloys are listed in Table 2. Variation on melting temperature, specific heat, enthalpy and thermal conductivity of used alloys depend on its compositions.

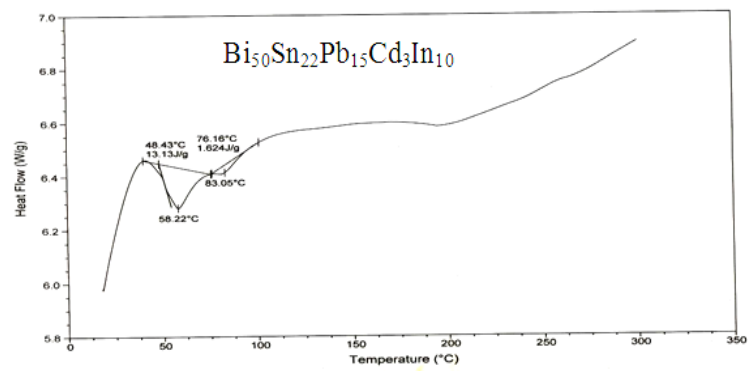

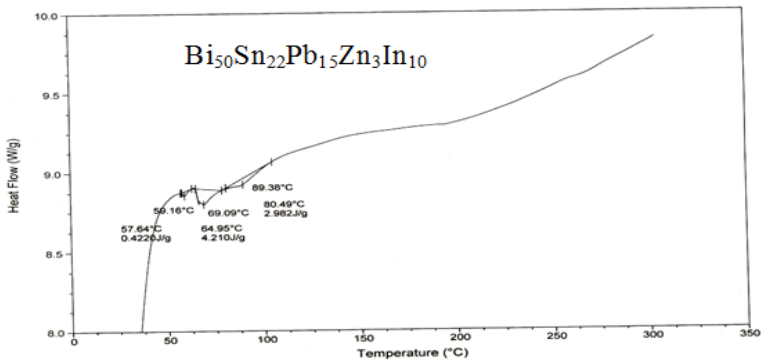
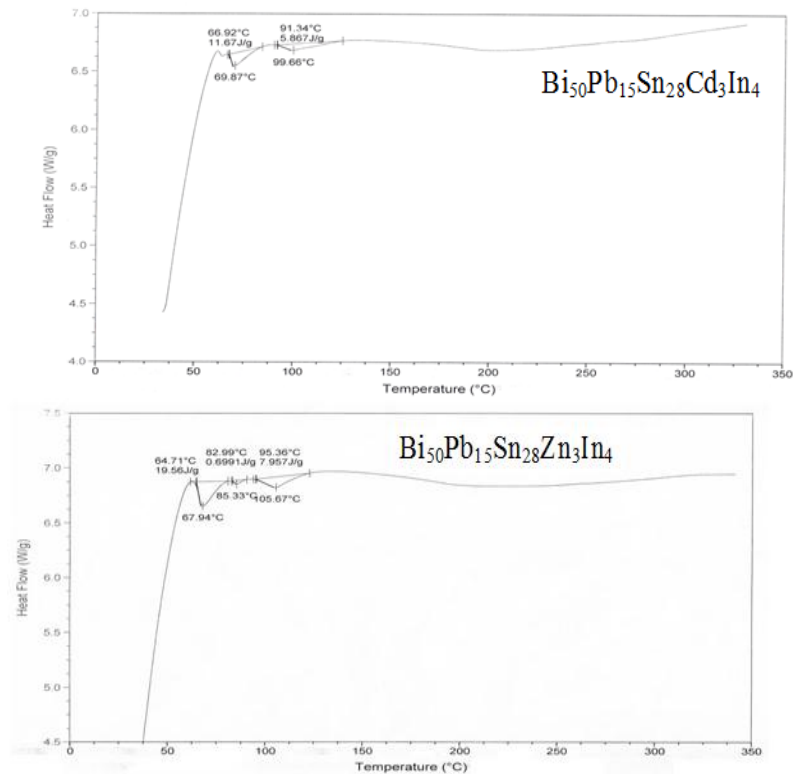

Figure 3:- DSC of penta $\mathrm{Bi}-\mathrm{Pb}-\mathrm{Sn}$ based alloys

Table 2:- melting point and other thermal properties of penta $\mathrm{Bi}$ - $\mathrm{Pb}-\mathrm{Sn}$ based alloys

\begin{tabular}{|c|c|c|c|c|}
\hline Samples & $\begin{array}{c}\text { Melting } \\
\text { point }{ }^{\circ} \mathrm{C}\end{array}$ & $\begin{array}{c}\mathrm{CP}_{\mathrm{P}} \\
\mathrm{J} / \mathrm{g} .{ }^{\circ} \mathrm{C}\end{array}$ & $\begin{array}{c}\Delta \mathrm{S} \\
\mathrm{J} / \mathrm{g} .{ }^{\circ} \mathrm{C}\end{array}$ & $\begin{array}{c}\mathrm{K} \\
\mathrm{W} . \mathrm{m}^{-1} \cdot \mathrm{K}^{-1}\end{array}$ \\
\hline $\mathrm{Bi}_{50} \mathrm{~Pb}_{15} \mathrm{Sn}_{22} \mathrm{Cd}_{3} \mathrm{In}_{10}$ & 58.22 & 0.596 & 0.224 & 0.398 \\
\hline $\mathrm{Bi}_{50} \mathrm{~Pb}_{15} \mathrm{Sn}_{22} \mathrm{Zn}_{3} \mathrm{In}_{10}$ & 69.09 & 0.314 & 0.059 & 0.701 \\
\hline $\mathrm{Bi}_{50} \mathrm{~Pb}_{15} \mathrm{Sn}_{28} \mathrm{Cd}_{3} \mathrm{In}_{4}$ & 69.87 & 0.743 & 0.157 & 0.700 \\
\hline $\mathrm{Bi}_{50} \mathrm{~Pb}_{15} \mathrm{Sn}_{28} \mathrm{Zn}_{3} \mathrm{In}_{4}$ & 67.94 & 1.387 & 0.274 & 0.429 \\
\hline
\end{tabular}

\section{Electrical resistivity}

Plastic deformation raises the electrical resistivity as a result of the increased number of electron scattering centers. Also crystalline defects serve as scattering center for conduction electrons in metals, so the increase in their number raises the imperfection. The measured electrical resistivity of $\mathrm{Bi}_{50} \mathrm{~Pb}_{15} \mathrm{Sn}_{22} \mathrm{In}_{10} \mathrm{X}_{3}$ and $\mathrm{Bi}_{50} \mathrm{~Pb}_{15} \operatorname{Sn}_{28} \mathrm{In}_{4} \mathrm{X}_{3}(\mathrm{X}=\mathrm{Cd}$ or $\mathrm{Zn})$ alloys are shown in Table 3. Electrical resistivity of $\mathrm{Bi}-\mathrm{Pb}$ - $\mathrm{Sn}$ - In alloys varied after adding $\mathrm{Cd} /$ or $\mathrm{Zn}$, which depend on alloys compositions. 
International Journal of Science and Engineering Applications

Volume 4 Issue 2, 2015, ISSN-2319-7560 (Online)

Table 3:- electrical resistivity and electrical conductivity of penta $\mathrm{Bi}-\mathrm{Pb}-\mathrm{Sn}$ based alloys

\begin{tabular}{|c|c|c|}
\hline Samples & $\rho \times 10^{-8} \Omega . m$ & $\sigma \times 10^{5} \Omega . m$ \\
\hline $\mathrm{Bi}_{50} \mathrm{~Pb}_{15} \mathrm{Sn}_{22} \mathrm{Cd}_{3} \mathrm{In}_{10}$ & 254.8 & 2.421 \\
\hline $\mathrm{Bi}_{50} \mathrm{~Pb}_{15} \mathrm{Sn}_{22} \mathrm{Zn}_{3} \mathrm{In}_{10}$ & 226.55 & 4.414 \\
\hline $\mathrm{Bi}_{50} \mathrm{~Pb}_{15} \mathrm{Sn}_{28} \mathrm{Cd}_{3} \mathrm{In}_{4}$ & 226.87 & 4.408 \\
\hline $\mathrm{Bi}_{50} \mathrm{~Pb}_{15} \mathrm{Sn}_{28} \mathrm{Zn}_{3} \mathrm{In}_{4}$ & 380.92 & 2.625 \\
\hline
\end{tabular}

\section{Mechanical properties}

The elastic constants are directly related to atomic bonding and structure. Elastic modului of $\mathrm{Bi}_{50} \mathrm{~Pb}_{15} \mathrm{Sn}_{22} \mathrm{In}_{10} \mathrm{X}_{3}$ and $\mathrm{Bi}_{50} \mathrm{~Pb}_{15} \mathrm{Sn}_{28} \mathrm{In}_{4} \mathrm{X}_{3}(\mathrm{X}=\mathrm{Cd}$ or $\mathrm{Zn})$ alloys are listed in Table 4. Elastic modulus values of $\mathrm{Bi}$ - $\mathrm{Pb}$ - $\mathrm{Sn}$ - In alloys changed after adding $\mathrm{Cd}$ / or $\mathrm{Zn}$ due to matrix structure change.

The resonance curves of $\mathrm{Bi}_{50} \mathrm{~Pb}_{15} \mathrm{Sn}_{22} \mathrm{In}_{10} \mathrm{X}_{3}$ and $\mathrm{Bi}_{50} \mathrm{~Pb}_{15} \mathrm{Sn}_{28} \mathrm{In}_{4} \mathrm{X}_{3}(\mathrm{X}=\mathrm{Cd}$ or $\mathrm{Zn})$ alloys are shown in Figure 4. Calculated internal friction and thermal diffusivity $\mathrm{Bi}_{50} \mathrm{~Pb}_{15} \mathrm{Sn}_{22} \mathrm{In}_{10} \mathrm{X}_{3}(\mathrm{X}=\mathrm{Cd}$ or $\mathrm{Zn})$ alloys are listed in Table 4. Internal friction of $\mathrm{Bi}-\mathrm{Pb}-\mathrm{Sn}$ - In alloys varied after adding $\mathrm{Cd} /$ or $\mathrm{Zn}$.

Table 4:- elastic modului, internal friction and thermal diffusivity of penta $\mathrm{Bi}-\mathrm{Pb}-\mathrm{Sn}$ based alloys

\begin{tabular}{|c|c|c|c|c|c|}
\hline Samples & $\begin{array}{c}\mathrm{E} \\
\mathrm{GPa}\end{array}$ & $\begin{array}{c}\mu \\
\mathrm{GPa}\end{array}$ & $\begin{array}{c}\mathrm{B} \\
\mathrm{GPa}\end{array}$ & $\mathrm{Q}^{-1}$ & $\begin{array}{c}\mathrm{D}_{\text {th }} \times 10^{-8} \\
\mathrm{~m}^{2} \text { Isec }\end{array}$ \\
\hline $\mathrm{Bi}_{50} \mathrm{~Pb}_{15} \mathrm{Sn}_{22} \mathrm{Cd}_{3} \mathrm{In}_{10}$ & 29.3 & 10.84 & 33.05 & 0.085 & 35.2 \\
\hline $\mathrm{Bi}_{50} \mathrm{~Pb}_{15} \mathrm{Sn}_{22} \mathrm{Zn}_{3} \mathrm{In}_{10}$ & 31.63 & 11.71 & 35.31 & 0.025 & 34.17 \\
\hline $\mathrm{Bi}_{50} \mathrm{~Pb}_{15} \mathrm{Sn}_{28} \mathrm{Cd}_{3} \mathrm{In}_{4}$ & 24.40 & 9.01 & 27.86 & 0.14 & 43.98 \\
\hline $\mathrm{Bi}_{50} \mathrm{~Pb}_{15} \mathrm{Sn}_{28} \mathrm{Zn}_{3} \mathrm{In}_{4}$ & 25.38 & 9.38 & 28.67 & 0.059 & 41.09 \\
\hline
\end{tabular}

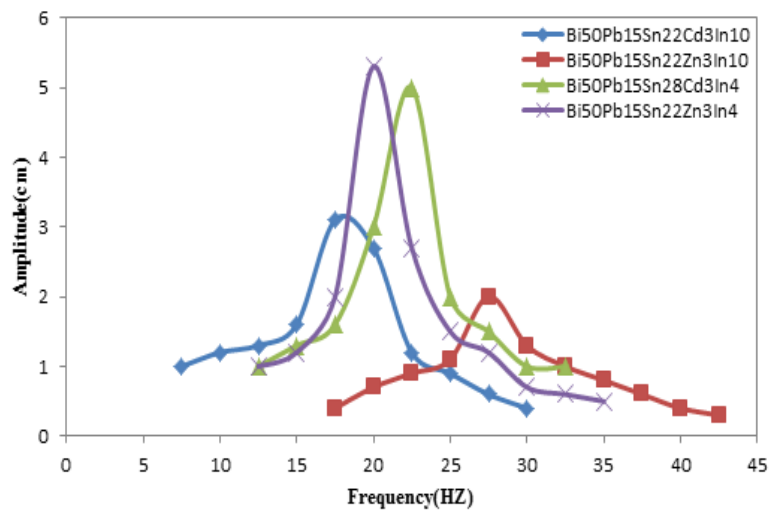

Figure 4:- resonance curves of penta $\mathrm{Bi}-\mathrm{Pb}-\mathrm{Sn}$ based alloys

\section{Vickers microhardness and minimum shear stress}

The hardness is the property of material, which gives it the ability to resist being permanently deformed when a load is applied. Vickers hardness of $\mathrm{Bi}_{50} \mathrm{~Pb}_{15} \mathrm{Sn}_{22} \mathrm{In}_{10} \mathrm{X}_{3}$ and $\mathrm{Bi}_{50} \mathrm{~Pb}_{15} \mathrm{Sn}_{28} \mathrm{In}_{4} \mathrm{X}_{3}(\mathrm{X}=\mathrm{Cd}$ or $\mathrm{Zn})$ alloys at 10 gram force and indentation time $5 \mathrm{sec}$ are exposed in Table 5. The minimum shear stress $\left(\tau_{\mathrm{m}}\right)$ of $\mathrm{Bi}_{50} \mathrm{~Pb}_{15} \mathrm{Sn}_{22} \mathrm{In}_{10} \mathrm{X}_{3}$ and $\mathrm{Bi}_{50} \mathrm{~Pb}_{15} \mathrm{Sn}_{28} \mathrm{In}_{4} \mathrm{X}_{3}(\mathrm{X}=\mathrm{Cd}$ or $\mathrm{Zn})$ alloys was calculated and then listed in Table 5. Vickers hardness of $\mathrm{Bi}-\mathrm{Pb}-\mathrm{Sn}$ - In alloys depend on its compositions.
Table 5:- Vickers hardness and minimum shear stress of penta $\mathrm{Bi}-\mathrm{Pb}-\mathrm{Sn}$ based alloys

\begin{tabular}{|c|c|c|}
\hline Alloys & $\mathrm{H}_{\mathrm{v}} \mathrm{kg} / \mathrm{mm}^{2}$ & $\mu_{\mathrm{n}} \mathrm{kg} / \mathrm{mm}^{2}$ \\
\hline $\mathrm{Bi}_{50} \mathrm{~Pb}_{15} \mathrm{Sn}_{22} \mathrm{Cd}_{3} \mathrm{In}_{10}$ & $9.72 \pm 1.1$ & 3.21 \\
\hline $\mathrm{Bi}_{50} \mathrm{~Pb}_{15} \mathrm{Sn}_{22} \mathrm{Zn}_{3} \mathrm{In}_{10}$ & $5.61 \pm 0.8$ & 1.85 \\
\hline $\mathrm{Bi}_{50} \mathrm{~Pb}_{15} \mathrm{Sn}_{28} \mathrm{Cd}_{3} \mathrm{In}_{4}$ & $21.82 \pm 1.13$ & 7.2 \\
\hline $\mathrm{Bi}_{50} \mathrm{~Pb}_{15} \mathrm{Sn}_{28} \mathrm{Zn}_{3} \mathrm{In}_{4}$ & $20.92 \pm 1.02$ & 6.9 \\
\hline
\end{tabular}

\section{CONCLUSIONS}

Microstructure (formed phases) of $\mathrm{Bi}_{50} \mathrm{~Pb}_{15} \mathrm{Sn}_{22} \mathrm{In}_{10} \mathrm{X}_{3}$ and $\mathrm{Bi}_{50} \mathrm{~Pb}_{15} \mathrm{Sn}_{28} \mathrm{In}_{4} \mathrm{X}_{3}(\mathrm{X}=\mathrm{Cd}$ or $\mathrm{Zn})$ alloys depend on alloys compositions. Physical properties (thermal, electrical and mechanical) of Bi- $\mathrm{Pb}-\mathrm{Sn}$ In- $\mathrm{X}(\mathrm{X}=\mathrm{Cd} /$ or $\mathrm{Zn})$ alloys effected by alloys compositions. The new alloy, $\mathrm{Bi}_{50} \mathrm{~Pb}_{15} \mathrm{Sn}_{22} \mathrm{Cd}_{3} \mathrm{In}_{10}$, has better properties for shielding blocks in mega-volt radiotherapy.

\section{REFERENCES}

[1] Kamal M, El-Bediwi A.B and Karman M.B, J. Mater. Sci.: Mater. Electro. 9 (1998) 425

[2] Kamal M, Ewaida M. A, Elleithy M. A and Dawod T. A, Mans.

Sci. Bull C. Nat. Sci. and Phys. Sci 27: 1(2000)

[3] Dawod T. A, M. SC. Thesis, Faculty of Science, Mansoura University, (2000)

[4] Kamal M, Mazen S, El- Bediwi A. B and El- Naggar M, Radia. Eff. \& Def. in Sol. 157 (2002) 467-474

[5] Kamal M, El-Bediwi A. B, J. Mater. Sci.: Mater. Electro. 11 (2000) 519-523

[6] Kamal M, Karman M. B and El-Bediwi A. B, U. Scientist Phyl. Sciences, 9: 2 (1997) 164

[7] Mc Cormack M, Chen H. S, Kammalott G.W, Jin S. J. Electron. Mater. 26: 8 (1997) 954

[8] Laine E, Lähteenmākl I, Lehtoranta I, J. Mater. Sci. 13 (1978) $108-112$

[9] Suryanara Yana C, Scripta Metall. 5 (1971) 337-40

[10] Borromêe-Gautier C, Giessen B. C and Grrant N. J, J. Chem. Phys. 48 (1968) 1905-11

[11] Straumanis W and Brakss N; Z. Phys. Chem., 30B (1935) 17

[12] Straumanis W and Brakss N;; Z. Phys. Chem. 38B (1937) 140

[13] Kamal M, Mazen S, El-Bediwi A, Kashita E, Radia. Eff. \& Def. in Sol. 161 (2006) 143-48

[14] Chriastelova J, Ozvold M, J. of alloys and compounds 457 (2008) 323-328

[15] Kamal M, Moharram B. M, Farag H, El-Bediwi A and Abosheiasha H. F, Radia. Eff. \& Def. in Sol. 161 (2006) 137- 142

[16] Kamal M, Mazen S, El- Bediwi A. B, Kashita E, Radia. Eff. \& Def. in Sol. 161 (2006) 143- 148

[17] Kamal M, Moharram B. M, Farag H, El-Bediwi A and Abosheiasha H. F, Radia. Eff. \& Def. in Sol. 161 (2006) 421- 425

[18] Kamal M, El-Bediwi A. B, Radia. Eff. \& Def. Sol. 159: 11- 12 (2004) 651- 657

[19] El-Bediwi A. B, A.M.S.E., 77: 4 (2004) Modelling A

[20] El-Bediwi A.B, A.M.S.E., 75: 3 (2002) 1

[21] Cullity B. D, "Element of x-ray diffraction" Ch.10 (1959) 297

[22] Sppinert S and Teffit W. E, ASTM, Proc. 61 (1961) 1221

[23] Schreiber E, Anderson O. L and Soga N, Elastic Constants and their Measurement, McGraw-Hill Book Company, Ch. 4 (1973) 